\title{
Crisis and risks in engineering project management: a review
}

Josivan Leite Alves ${ }^{1}$, Edivan Alexandre Ferreira', Jeniffer de Nadae ${ }^{2}$

${ }^{1}$ University of São Paulo - USP, Production Engineering of Polytechnic School, São Paulo, SP, Brazil.

${ }^{2}$ Federal University of Itajuba - UNIFEI, Production Engineering and Management Institute, Itajubá, MG, Brazil.

How to cite: Alves, J.L., Ferreira, E.A and Nadae, J. (2021), “Crisis and risks in engineering project management: a review", Brazilian Journal of Operations \& Production Management, Vol. 18, No. 4, e2021991.

https://doi.org/10.14488/BJOPM.2021.026

\section{ABSTRACT}

Goal: This paper performs a literature review to identify and analyze the main gaps related to crisis management and risk management in the engineering projects context.

Design / Methodology / Approach: A literature review research design was carried out merging bibliometrics, network and qualitative and quantitative content analysis. Data were obtained from the scientific database Scopus.

Results: Publications per year illustrates that in 2016 as concentrated the major number of papers. Only $1 \%$ of the authors published 4 papers about models for software engineering risks analysis and reduction. The paper distribution by country shows that the United States has the highest percentage, about $16 \%$ of the total. The network of co-occurrence of all keywords has three well-defined clusters.

Limitations of the investigation: The quantity of papers analyzed and the selection of a single database.

Practical implications: This research encourages project managers to develop pertinent skills for crisis management and risk management in the engineering projects context. Furthermore, this study can guide decision-makers on how to manage risks during the crisis, and also highlights the importance of creating a lessons learned database.

Originality / Value: The current study can contribute to companies catching lessons learned from literature, helping project managers to motivate the team during the crisis scenarios, to perform an effective struggle during the crisis, and to turn to the former position in a short time after the crisis.

Keywords: Crisis; Project Management; Risk; Engineering; Bibliometric Analysis.

\section{INTRODUCTION}

The scale and pace of crises make project management even more complex, so efforts and decisions must integrate new technologies and methods, deal with rapidly changing infrastructure and understand the risks involved (Schimak et al., 2020).

Additionally, every crisis is unique and unpredictable in terms of the socioeconomic, political, and environmental contexts. For this reason stakeholders can find barriers to interpreting or responding to crises, as they do not have enough information to ensure organizational agility in decision making (Kroener et al., 2019). A crisis can negatively affect the achievement of organizational goals (Bannerman, 2008).

Organizations must include external disturbances as an issue in the project management, moreover, reorganize themselves in a way that does not change the scope and structure of

Financial support: None.

Conflict of interest: The authors have no conflict of interest to declare.

Corresponding author: josivanleite3@gmail.com

Received: 2 Feb 2020.

Approved: 18 Feb 2021.

Editor: Julio Vieira Neto. 
their project. Also, stakeholders are required to be able to assess and quantify project risks in a crisis context. Risk and crisis management are two complementary stages, which aim to develop the organization's capacity to face adversity and disruption (Paraskevas and Quek, 2019).

As projects have budgetary uncertainties and restrictions, project managers are responsible for identifying and mitigating these risks. Besides, the engineering project's complexity requires risk management and forecasting capabilities, since these projects have several interdependent elements. As a result, it is difficult to apply the traditional risk matrices (Rahahleh and Omoush, 2019).

A well-structured risk management approach also improves and encourages greater identification of opportunities for continuous improvement (Zeng et al., 2010) and crisis management helps decision making. Undoubtedly, crisis management is a systematic effort that guides organizational decisions and actions, trying to avoid or manage the project collapse (Bannerman, 2008).

The recent crisis caused by the COVID-19 was unexpected, affecting the people's health and nations' economy, lead to challenges for the project managers. In this scenario, overhauled the projects, reallocated internal resources, reevaluated construction teams' safety precautions and forced project managers to reassessed which deliverables were accomplished (Yellow Brick Consulting, 2020).

Furthermore, engineering projects, are characterized by high-risk management (Bubnov et al., 2015) and high probabilities of failure (Miller and Lessard, 2001). Besides, are considered more complex with increased risks in a global market, as a result of intensive technologies and high investment (Liu et al., 2017) and can be more affected by the global crisis.

The engineering project parameters are themselves uncertain; product price, price of raw materials, and the inflation index, for example, are affected by risk events, such as the breakout of the global financial crisis (Liu et al., 2017).

Any project manager's desire during a crisis is to minimize the damage, so the principles of project management can help them (Sawle, 1991). Engineering projects have greater challenges because they are considered low efficiency, and a lot of them are unable to achieve their initial goals (Zhu and Mostafavi, 2018).

In this perspective, this paper performs a literature review to identify and analyze the main gaps related to crisis management and risk management in engineering projects context. Furthermore, this paper seeks to answer the following research questions: (RQ\#1) Which are the main topics relating the crisis and risk management to the engineering project context?

Based on the first question findings and to identify managers' expertise to manage risk and crisis in engineering projects, the second research question is suggested: (RQ\#2) What are the tools, actions and skills needed for risk and crisis management in engineering projects?

To identify future research agendas, the third question is proposed: (RQ\#3) What are the most updated thoughts, trends, and gaps in the literature?

To answer these questions, a comprehensive literature review research design was carried out merging bibliometrics, network, and qualitative and quantitative content analysis.

The paper is organized into five sections. Section 1 contextualizes the topic addressed. A brief presentation of the concepts is shown in Section 2 followed by Section 3, which presents the research design. In Section 4, the results and discussion are present, under which the main contributions on the theme of this study, followed by the content analysis to answer the research questions. Section 6 presents the conclusions.

\section{CRISIS AND RISKS IN ENGINEERING PROJECT MANAGEMENT}

Projects can be defined as a temporary effort to achieve unique and exclusive results (Project Management Institute, 2013). Since the 1950s, project management has evolved. Much has already been developed, applied, and improved concerning engineering project 
planning (Söderlund and Lenfle, 2013). With the technological evolution and the complexity execution of projects, methodologies effective in the past, are no longer adequate due to the degree of complexity that the projects took (Shenhar, 2011).

Each project has its particularities making them unique and with differentiated efforts for their management (Baccarini, 1996). And traditional project management models are identified when it comes to managing the project.

Traditional project management models are concerned with achieving three objectives: time, budget, and project requirements, called "the triple constraint" by Shenhar (2011). If projects reach these goals, they can become successful.

Over the last five decades, project management tools and techniques created to facilitate the successful delivery of engineering projects (Zhu and Mostafavi 2018). Engineering projects are ubiquitous across different industries, such as aerospace, shipbuilding, and construction (Zhu and Mostafavi, 2018). Many of them are large complex projects operating in dynamic environments (Zhu and Mostafavi, 2018).

Moreover, to manage any project skills are required, such as dimensioning resources, planning, execution, strategy development, and the diagnosis of the risk (Geraldi et al., 2011; Vencato, 2014; Consoni and Colauto, 2016). For Vencato (2014), the risks must be managed after defining the project scope, ensuring better risk management.

Projects classified as complex are the most likely to suffer from the risks in this situation, as they frequently have problems in requirements definition. (Rovai et al., 2013). The Project Management Institute (2004) defines project risk as related to all events or conditions that can generate positive or negative outcomes in the project objective; risks classified as internal and external.

One of the key project management processes is risk management (Raz et al., 2002). Additionally, risks can be divided into internal and external. For Keeling (2005), the internal risks are from the project itself and can be controlled and external risks are related to external situations, such as policies and crises, thus being uncontrollable factors.

In addition, the goals of risk management are to identify project risks and develop strategies that either significantly reduce them or take steps to avoid them (Wideman, 1992).

Thus, not worrying about risk management in the conception of the project's scope can result in a negative impact on project development. According to Raz et al. (2002), each project must be prepared to face risks because they are inherent in the project. Otherwise, the greater the risks, the greater the likelihood of errors occurring.

For Raz et al. (2002) and Pinheiro et al. (2006) more numerous the project's uncertainties, the greater the risks are taken by him, so risk management becomes essential for the project management. Therefore, risk management aims to identify potential threats that may occur, thus reducing any negative impact on the project's objectives and success (Masso et al., 2020).

Molina Palma et al. (2011) emphasize that the project maturity level helps managers analyze the project risks qualitatively or quantitatively. For new projects (without historical data series and processes) the qualitative analysis techniques are advisable. If not (data provides statistical analysis), it is advisable to use quantitative tools.

Raz et al. (2002) highlight that risk management provides organizations with the best fulfillment of goals and budget. However, risk management is only really carried out in complex projects. So, for complex projects, with high levels of complexity and uncertainties, the policies for the risk contingency need to be included in the project scope.

For Project Management Institute (2013), risk management can increase the positive and decrease the negative impacts. Furthermore, risk management comprises the following processes: planning risk management, identifying risks, conducting a qualitative risk analysis, performing quantitative risk analysis, planning risk responses, controlling risks (Project Management Institute, 2013). Some principles of ISO 31000 (2009) identify opportunities for providing risk management: improving the opportunities and threats identification, allocation and use of resources in the risk treatment, minimizing losses, improving organizational learning, and organizational resilience. 
Fairley (1994) shown the steps to the risk management process: Identify risk factors, assess risk probabilities and effects on the project, develop strategies to mitigate identified risks, monitor risk factors, invoke a contingency plan, manage the crisis, and finally Recover from the crisis.

Crises manifest themselves in unexpected outbreaks of a considerable number of otherwise minor unmanaged risks, or the immediate adverse influence of the greatest risk (Vondrušk, 2014). The crisis is "often defined as a serious threat to the basic structures or the fundamental values and norms of an organization which, under time pressure and highly uncertain circumstances, necessitates the making of critical decisions" (Pearson and Clair, 1998). The crisis is also expressed as a period of a sudden change during which a new system is formed (Howsawi et al., 2014).

Additionally, the response to the crisis seems to be reactive, intuitive, and based on prior background and proposes managing the results as effectively and efficiently as possible (Paraskevas and Quek, 2019).

As can be seen, the common theme between the definitions of 'risk' and 'crisis' is uncertainty and both may originate from an internal or an external threat (or threats). Despite their difference is the fact that risk may or may not occur at some point soon whereas a crisis is unexpected and can occur anytime. Still, the crisis is characterized by ambiguity of cause, effect, and means of resolution, and necessitates immediate action (Pearson and Clair, 1998).

Given the above, "risk and crisis management are not two separate functions but rather two learning-based complementary stages of the same function which aims at developing the capacity of the organization to face adversity and disruption with no or limited consequences and recover quickly from any crisis". (Paraskevas and Quek, 2019). The meaning of a crisis includes opportunity, risk, uncertainty, threat, conflict, accident, and instability (Öcal et al., 2006).

Ultimately Project Management Institute (2013) proposed a project management definition that can be used during a crisis "the application of knowledge, skills, and techniques to execute and deliver projects effectively and efficiently in a situation or time at which a nation faces intense difficulty, uncertainty, danger or serious threat to people and national systems and organizations and a need for non-routine rules and procedures emerge accompanied with emergency".

\section{RESEARCH METHODS}

The research method combines quantitative and qualitative strategies, including bibliometric analysis, content analysis, and a systematic literature review. Because of the great number of academic papers, bibliometric studies are more appropriated because are recognized as a systematic and relevant approach (Ikpaahhindii, 1985; Neely, 2005).

The content analysis allows an in-depth understanding of the research constructs and their relationship (Duriau et al., 2007). The procedures were organized at each stage of the research protocol proposed by Littell et al. (2008), following three steps: data collection, data analysis, and synthesis. It merges bibliometrics, and content analysis because these methods are complementary (Carvalho, 2013).

The bibliometric analysis is the quantitative study of literature, it analyzes the growth, and maturation of scientific publications, on a theme (Moral-Muñoz et al., 2020). And it allows to analyze current trends in the literature about a specific area and use guidance for future research (Muhuri et al., 2019).

Aligned to the research objectives of mapping the literature on the themes, a systematic literature review (SLR) approach was selected to answer the three research questions (RQs) as highlighted in the introduction section. The systematic review of the literature aims to gather and evaluate all studies related to a topic of interest (research objective), achieving the results exempt and impartial (Zied Milian et al., 2017). 
Data were obtained from the scientific database Scopus by late April 2020. The Scopus database is considered the largest database of abstracts and citations in the peer-reviewed literature: scientific periodicals, books, and congress proceedings (Scopus, 2018).

Also, the database provides compatible metadata for bibliometric analysis software, carrying the articles' abstracts, references, citation indexes, authors, institutions, and countries, among others (Carvalho et al., 2013).

The search string used was risk* OR uncertaint* AND cris* AND project* AND engineering applied as "titles, keywords, and abstracts" in Scopus, resulting in 209 articles in Scopus. Within this number, 6 articles were duplicated (found in the database). The only filter applied was "type of documents", choosing only "articles", "reviews" and "articles in press" because of the robustness of the pairwise review process (Takey and Carvalho, 2016).

Then, we excluded 13 papers that all agreed did not fit the research scope. These 13 papers were about: laboratory procedures in biomedical engineering and genetic engineering, theoretical and philosophical reflections on crises, description of the complexity of some numerical calculation, and risks in studies related to the genome of microorganisms.

When there is no consensus among authors, the full paper was analyzed and discussed. Next, the snowball sampling technique was employed to identify the most relevant references that were not retrieved in the initial sample, considering the most cited studies that fit the research scope, using the same screening process. A final selected sample of 190 articles resulted from this process and the bibliometric indicators selected. Table 1 shows research questions and methods.

Table 1: Research questions and methods

\begin{tabular}{llcc}
\hline$\#$ & \multicolumn{1}{c}{ Reasearch Question } & Method & Software \\
\hline 1 & $\begin{array}{l}\text { Which are the main topics relating the crisis and risk } \\
\text { management to the engineering project context? }\end{array}$ & $\begin{array}{l}\text { Bibliometrics and } \\
\text { content analysis }\end{array}$ & Excel \\
\hline 2 & $\begin{array}{l}\text { What are the tools, actions and skills needed for risk and } \\
\text { crisis management in engineering projects? }\end{array}$ & $\begin{array}{c}\text { Semantic and } \\
\text { content analysis }\end{array}$ & $\begin{array}{c}\text { VOSviewer } \\
\text { and Excel }\end{array}$ \\
\hline 3 & $\begin{array}{l}\text { What are the most updated thoughts, trends, and gaps in } \\
\text { the literature? }\end{array}$ & $\begin{array}{l}\text { Bibliometrics and } \\
\text { content analysis }\end{array}$ & $\begin{array}{c}\text { VOSviewer } \\
\text { and Excel }\end{array}$ \\
\hline
\end{tabular}

Source: authors (2020).

Therefore, the sample was grouped by years, countries/territories, most cited papers, and keyword co-occurrence networks. In each of these indicators, the main contribution of each paper was sought. For this reason, all 190 papers were read in full.

In the content analysis, papers analyzed finding the authors' relevance, objective, and contributions to project management or engineering risk management. The content analysis showed the factors and actions that influence the engineering project management, and the risks inherent to decisions taken in crisis.

Moreover, measures of centrality, dispersion, and the application of Lotka's Law were used to verify the data obtained in the sample of this research.

\section{RESULTS AND DISCUSSION}

\subsection{Bibliometric and Network Analysis}

The evolution of the publications on crisis management and risk management in engineering projects context is considerably dispersed, with two production peaks, in 2009 and 2016. In terms of dispersion measures, there is a variance of 29.4 and a standard deviation of 5.42. Also, from 1976 to 2007, publications are below average $(<6.6)$, while from 2008 to 2020 it is higher, see Figure 1. 


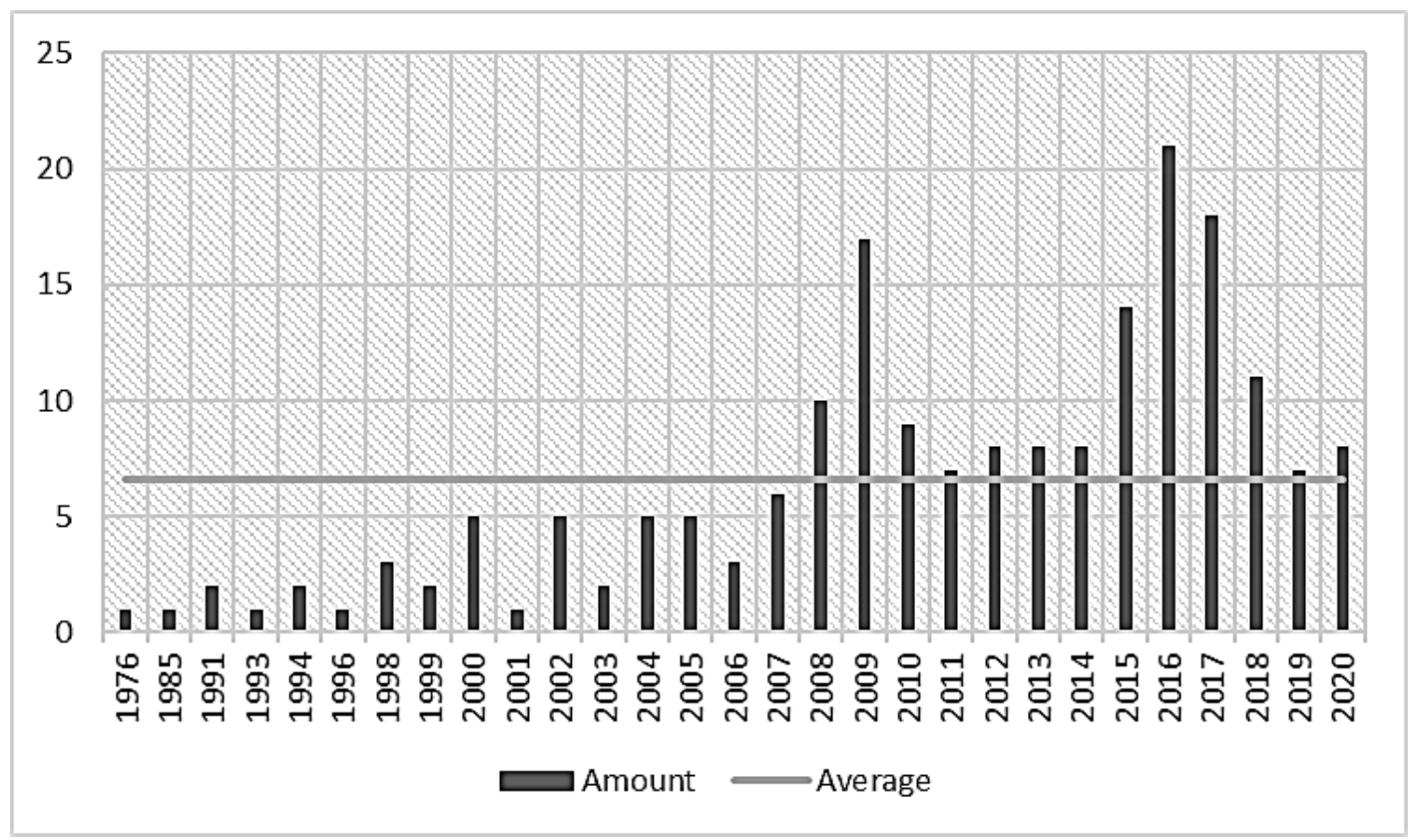

Figure 1. Evolution of the publications on crisis management and risk management in of engineering projects context.

Publication peaks occurred during or after crisis events, whether environmental or economic. In 2008 publications focus on support for the decision-making process in crises, more specific projects software. In 2009 papers focus on analysis for project risk management and decision strategies. In 2015 and 2016, productions apply mathematical models for risk analysis in emergency scenarios. As for 2017 publications, approach risk analysis and project management in the most diverse engineering projects, through quantitative and qualitative studies.

Around 159 authors have an average of 1.18 papers per author, with a variance of 0.23 and a standard deviation of 0.48 . However, only $1 \%$ of the total produced 4 papers about framework and models for software engineering risks analysis and mitigation. Compared to $60.8 \%$ of Lotka's Law, the productivity of these authors exceeded $25.2 \%$, meeting the assumptions of this law, which states that most authors publish only one article and few authors have more important production (Table 2).

Table 2: Authors and article productivity

\begin{tabular}{cccc}
\hline $\begin{array}{c}\mathbf{N}^{\circ} \text { of contributions by } \\
\text { author } \mathbf{x}\end{array}$ & $\mathbf{N}^{\mathbf{0}}$ of authors & \% of authors & Accumulated \% \\
\hline 4 & 2 & 0.012578616 & 0.012578616 \\
\hline 3 & 1 & 0.006289308 & 0.018867925 \\
\hline 2 & 20 & 0.125786164 & 0.144654088 \\
\hline 1 & 136 & 0.855345912 & 1 \\
\hline Total & 159 & 1 & - \\
\hline
\end{tabular}

Source: authors (2020).

The paper per country shows that the United States has the highest percentage, about $16 \%$ of the total, followed by China (8\%) and France (7\%). Australia, Canada, Italy, and the United Kingdom (5\% each), while Brazil and Portugal have 3\%. Based on these data, Figure 2 details the number of scientific publications distributed around the globe. 


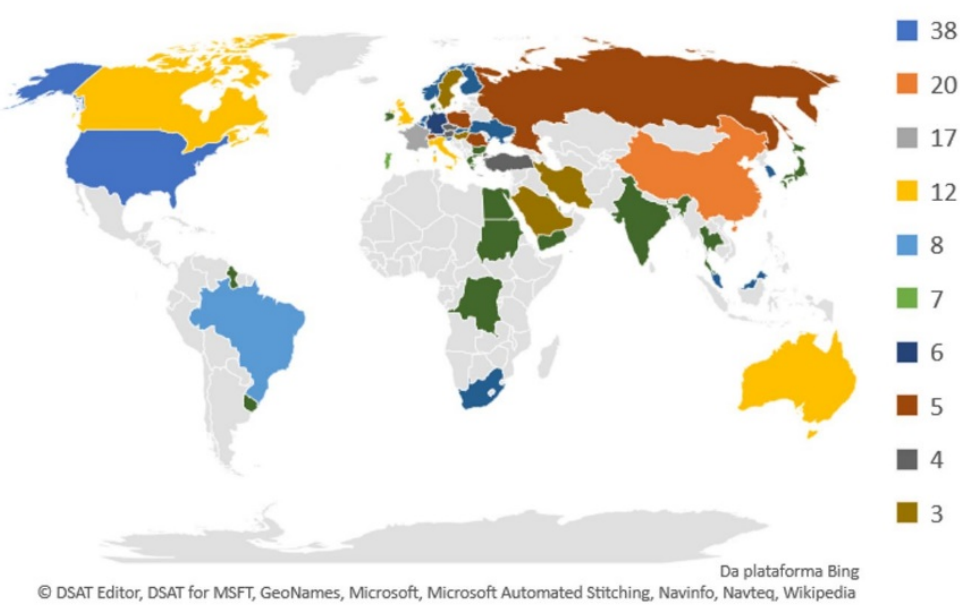

Figure 2. Publications by country/territory

Table 3 summarizes the country research approach with a percentage equal to or greater than $3 \%$.

Table 3: Country research approach

\begin{tabular}{|c|c|}
\hline Country & Approach \\
\hline United States & $\begin{array}{l}\text { Risk analysis through mathematical modeling, definition, control, and management } \\
\text { of risks in projects and sustainability, risks in port infrastructure projects, analysis of } \\
\text { and failures in the supply of electricity, research in the area of Genetic and } \\
\text { Environmental Engineering, risks in projects sustainable complexes. }\end{array}$ \\
\hline China & $\begin{array}{l}\text { Uncertainties in civil construction projects. Analysis of uncertainties using } \\
\text { mathematical models, risks in the management of water resources, urban } \\
\text { infrastructure projects management, the effects of crisis from 2008, and analysis of } \\
\text { energy generation projects. }\end{array}$ \\
\hline France & $\begin{array}{l}\text { Training of human resources and skills for project management in emergencies or } \\
\text { crisis scenarios; risk management in Software Engineering projects; crisis } \\
\text { management; environmental crisis management plan; and monitoring risk in oil and } \\
\text { gas projects. }\end{array}$ \\
\hline Australia & $\begin{array}{l}\text { The risks of using treated water, identification of risks in civil construction; the effects } \\
\text { of the } 2008 \text { financial crisis; risk management to improving performance in software } \\
\text { projects; and application of computational tools for crisis identification. }\end{array}$ \\
\hline Canada & $\begin{array}{l}\text { Failures in software projects; structural risks in hydro sanitary installations on public } \\
\text { roads; the crisis in urban infrastructure; and risk analysis in the different Civil } \\
\text { Engineering projects. }\end{array}$ \\
\hline Italy & $\begin{array}{l}\text { Prevention of risks and natural disasters; Software Engineering projects for the } \\
\text { development of algorithms; analysis of aspects of reliability and risk of the gas } \\
\text { network under normal load and extreme crises; management of water resources in } \\
\text { the face of droughts and floods. }\end{array}$ \\
\hline $\begin{array}{l}\text { United } \\
\text { Kingdom }\end{array}$ & $\begin{array}{l}\text { These are mostly research in Civil Engineering projects, such as risk mitigation } \\
\text { strategies for wind farms, wealth analysis in the construction of dams for possible } \\
\text { floods, and training of employees for risk control with a focus on the safety of } \\
\text { workers. }\end{array}$ \\
\hline Brazil & $\begin{array}{l}\text { Risk management in Software Engineering projects, risk analysis in sustainable } \\
\text { projects, analysis in the Genetic Engineering area, and decision making based on risk } \\
\text { analysis. }\end{array}$ \\
\hline Portugal & $\begin{array}{l}\text { Emergency management systems; risk analysis as a strategic project management } \\
\text { tool; and risk assessment in software projects (surveys about at project failures). }\end{array}$ \\
\hline
\end{tabular}

Source: authors (2020). 
Table 3 papers address the effects of risks in environmental and economic crises on project management. Brazilian publications do not deal with environmental disasters, while those in Italy do not deal with financial crises. Of all, only the United Kingdom analyzes the effects of a health crisis, more specifically the epidemics. Another important aspect is that papers have emerged in all these countries that deal with the concept of software crisis. It is a consensus that the software crisis is associated with a set of problems in Software Engineering projects, related to use, development processes, maintenance, and resource management.

Research with unidentified countries whose authorship did not inform nationality identified about $4 \%$ of the sample. These surveys primarily address mathematical modeling for hydrological studies and flood forecasting in real-time, flood management, risk analysis, and assessment, as well as the consequences of possible climate crises.

Another important bibliometric indicator is the publications with the highest number of citations, shown in Table 4.

Table 4: Scientific productions with more than 100 citations

\begin{tabular}{cccc}
\hline Paper & Year & Authors & $\begin{array}{c}\text { \#Total } \\
\text { Citations }\end{array}$ \\
\hline $\begin{array}{c}\text { A replicated survey of IT software project } \\
\text { failures }\end{array}$ & 2008 & $\begin{array}{c}\text { El Emam and Koru } \\
(2008)\end{array}$ & 181 \\
\hline $\begin{array}{c}\text { CRISPR, the disruptor } \\
\text { Fuzzy cash flow analysis using present worth } \\
\text { criterion }\end{array}$ & 1994 & Chiu and Park (1994) & 157 \\
\hline $\begin{array}{c}\text { A hybrid approach to concept selection through } \\
\text { fuzzy analytic network process }\end{array}$ & 2009 & $\begin{array}{c}\text { Ayağ and Özdemir } \\
\text { (2009) }\end{array}$ & 142 \\
\hline Risk management of software projects & 1994 & Fairley (1994) & 120 \\
\hline
\end{tabular}

Source: authors (2020).

El Emam and Koru (2008) aim to rate the cancellation of projects in Software Engineering and whether there was a moment of crisis. These authors explain three main reasons for project failure, first requirements and changes in scope, the second lack of senior management involvement, and the third lack of budget and lack of project management skills. Regarding project success, the authors argue that organizational maturity, methodology, and project management experience directly affect project success.

Ledford's research (2015) reports the use of the Clustered Regularly Interspaced Short Palindromic Repeats- CRISPR technique in Bioengineering, explaining their advantages in genome editing and selective DNA study. Chiu and Park (1994) analyze uncertainty about future cash flows of the engineering sector, using the triangular fuzzy numbers, arguing that cash flows are defined as clear numbers or risk probability distributions. Also, Chiu and Park (1994) propose an economic engineering decision model in which uncertain cash flows and discount rates are specified as triangular fuzzy numbers. Ayağ and Özdemir (2009) evaluate a set of conceptual design alternatives developed in an Analytic Network Process (ANP) environment, to alternatively satisfy the needs and expectations of customers and the engineering specifications of the organization. However, these authors do not relate their research to project management in crises.

On the other hand, Fairley's (1994) approach regarding risk management in software projects. It sets out seven steps considered in risk management: identify risk factors (1), assess risk probabilities and effects on the project (2), develop strategies to mitigate identified risks (3), monitor risk factors (4), invoke a contingency plan (5), manage the crisis (6), and recover from the crisis (7).

For the conception of the keyword correlation network, using VOSviewer software. Figure 3 shown at least ten occurrences of each keyword. 


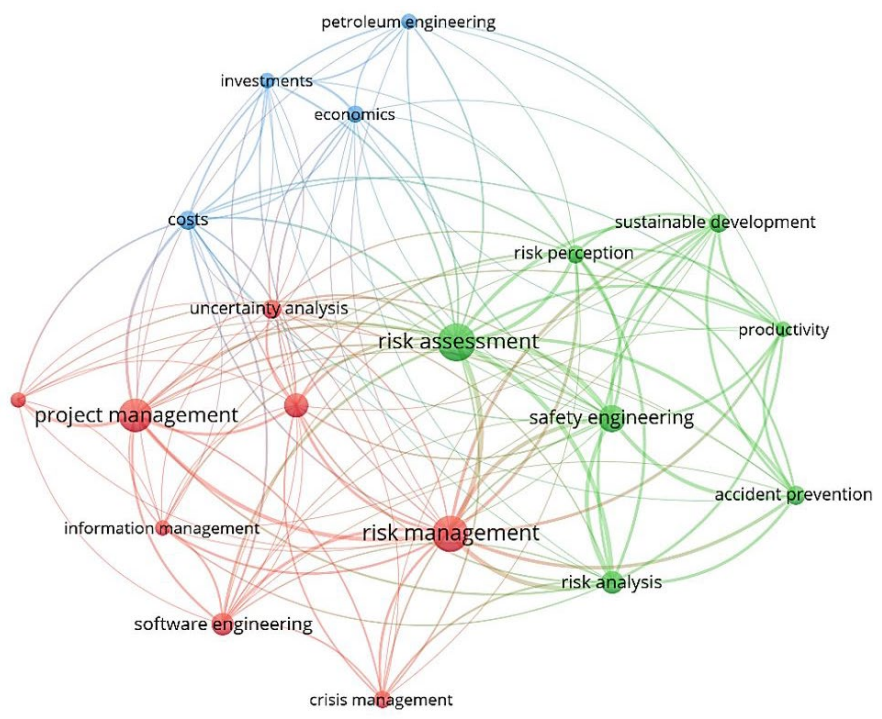

Figure 3. Co-occurrence of all keywords

The network has three clusters. The blue cluster denotes analysis of Petroleum Engineering projects concerning investments and costs. The Green denotes research aimed at the treatment, analysis, and risks assessment, focusing on sustainability, safety, and productivity. Being strongly linked to the green cluster, the red encompasses research that addresses risk management and project management with an emphasis on Software Engineering projects, in addition to the analysis of uncertainties and crisis management.

Finally, most of the research uses case studies as a methodology (about 23.6\%), followed by descriptive analysis by $16 \%$ (usually from some management system) and literature reviews (11.3\%). Surveys (9.4\%), quantitative analyzes with mathematical models' application (7.5\%), multicriteria models for decision making application (7.5\%, the Analytic Network Process and Analytic Hierarchy Process), and action research $(4,7)$.

In crisis scenarios, monitoring resources are needed to map the parameters of effectiveness and the efficiency of organizational actions. Besides, planning and management are crucial to have an answer to the effectiveness of humanitarian actions, post-crisis reconstruction projects, and planning within disaster management (Bally et al., 2005). Kesavan (2016) still considers that project management during a crisis becomes critical and some actions, set out in Table 5, are necessary for finish the project.

Table 5: Guidelines for project management during crisis

\begin{tabular}{|c|c|}
\hline Stage & Actions \\
\hline Initiation & $\begin{array}{l}\text { A clear and objective scope definition, the project status, the assignment of } \\
\text { responsibilities, and the identification of stakeholders, as well as knowledge of all } \\
\text { project deliverables. }\end{array}$ \\
\hline Planning & $\begin{array}{l}\text { Systematic and detailed formal planning, as well as resource estimation and risk } \\
\text { identification. Besides, prioritizing and sequencing activities, reducing downtime } \\
\text { for materials and labor. }\end{array}$ \\
\hline Execution & $\begin{array}{l}\text { Overcoming goals, managing human resources to make them more productive, } \\
\text { ensuring that the communication process is effective among team members, } \\
\text { creating a succession plan for unexpected layoffs. }\end{array}$ \\
\hline $\begin{array}{c}\text { Monitoring and } \\
\text { control }\end{array}$ & $\begin{array}{l}\text { Continuously evaluate the progress of the project, using management monitoring } \\
\text { tools established in the planning. Hold regular meetings with team members, } \\
\text { assess risks, and propose solutions, create performance indicators for the project } \\
\text { schedule, costs, and performance. }\end{array}$ \\
\hline Closing & $\begin{array}{l}\text { Formally finish the project, analyze the success, failures, and lessons learned. } \\
\text { Thus, a database or management models is created amid a crisis. }\end{array}$ \\
\hline
\end{tabular}

Source: Kesavan (2016, p5). 


\subsection{Content analysis: Crisis and Risk management in projects}

Furthermore, during a crisis, leadership is needed that can drive the necessary changes in the project management process, also know the supply chain as a whole. It is essential to establish partnerships and that the project deliveries reduce the challenges of complexity and time. Thus, there are considerable gains in reducing engineering project costs and schedules (Reid et al., 2016).

For Rousseaux and Lhoste (2008), it is necessary to implement operational crisis management in three parts: a) early operational management: planning emergency actions, allocating the necessary resources, and optimizing the main parameters; b) operational management in real-time: to update the situation and decision parameters and to make plans compatible with reality; c) return to operational management allocated efficiently.

Regarding project management tools Paggio et al. (1999) emphasize the use of TRAnsferring CHARADE technology in Central and Eastern Europe-TRACE, a system for emergency management in real-time, whose main objective is to assist the during an environmental crisis and to build an effective intervention plan. TRACE divides its actions into forecast (risk analysis, forecasts), medium / long term planning, monitoring and surveillance, crisis/emergency management, assessment, and recovery of post-incident damage.

Baldi et al. (2012) also describe the use of a tool, QUATER (TERritorial QUAlity, territorial risk management systems of a municipality). They point out that this tool provides guidelines for the definition of short- and long-term government policies, guidelines for emergency management, for information and communication campaigns and strategies for territorial reallocation of communities in risk areas.

Cabal and Erlich (2018) cite the use of the CRISMA - Modeling crisis management system developed by the French government after the Xynthia storm in 2010. The system allows simulating possible crises in various sectors, evaluates the consequences of an incident, simulates the impacts of combat actions the crisis. The CRISMA also evaluates strategies, investments applied, reserves, inventories, and assists in the crisis management plan.

Wybo and Van Wassenhove (2016) propose a profile and skills of HSE (Health, Safety, Environment) professionals in the face of activities that need quick responses and in critical situations. HSE professionals must have the ability to manage multiple tasks simultaneously, some of which require planning, cognitive resources, and time. Regarding the curricula of these professionals, the research showed the following themes: advising management and decision-makers, the definition of the missions and the organization of the safety management system, risk management (hazard identification, evaluation and control), regulatory compliance, diffusion of safety culture and culture change, training and communication, accident and incident investigation, emergency and crisis management, monitoring and reporting, knowledge management and insuring and costing risks.

Table 6 shown the papers classified into five different types of risk assessment process according to ISO 31000 (2009).

Table 6: Risk assessment processes classification by ISO 31000 (2009)

\begin{tabular}{cl}
\hline \multicolumn{1}{c}{ Risk assessment process } & \multicolumn{1}{c}{ Authors } \\
\hline \multirow{2}{*}{ Risk identification } & $\begin{array}{l}\text { Shafiee (2015); Hurlimann (2007); Zeng et al. (2010); } \\
\text { Watremez et al. (2016); Wagner et al. (2016). }\end{array}$ \\
\hline \multirow{2}{*}{ Risk analysis } & $\begin{array}{l}\text { Kesavan (2016); Viliani et al. (2016); Kostuk et al. (2006); Li and } \\
\text { Knights (2009); Ávila Filho et al. (2016). }\end{array}$ \\
\hline \multirow{2}{*}{ Risk assessment } & $\begin{array}{l}\text { Holla et al. (2013); Lueke and Ariaratnam (2000); Song et al. (2018); } \\
\text { Li et al. (2020). }\end{array}$ \\
\hline \multirow{2}{*}{ Risk treatment } & $\begin{array}{l}\text { Reid et al. (2016); Bannerman (2008); Toffolon and Dakhli (2002); } \\
\text { Cabal and Erlich (2018); Xu and Li (2012); Che et al. (2014). }\end{array}$ \\
\hline \multirow{2}{*}{ Monitoring and critical analysis } & $\begin{array}{l}\text { Wong (2012); Paggio et al. (1999); Ousmane and Abdullah (2018); } \\
\text { Power et al. (2013); Whelan et al. (2002). }\end{array}$ \\
\hline
\end{tabular}

Source: authors (2020). 
Table 6 shows the treatment of risks, usually using case studies methodology and monitoring of software projects. But they do not restrict their analysis to only one phase of risk management. In the identification, the studies list the risks that will not be analyzed or that were research results. In the analysis and treatment of risks, the authors seek external sources to substantiate their considerations. The treatment and monitoring of risks are done through specific software for the management of projects.

Briefly, Table 7 shown recurrent themes in the papers.

Table 7: The main topics covered by author

\begin{tabular}{|c|c|}
\hline Recurring themes & Authors example \\
\hline Software crisis and management & $\begin{array}{l}\text { Toffolon and Dakhli (1998); Szczepaniak et al. } \\
\text { (2001); Moreno (2005). }\end{array}$ \\
\hline Risk management and project uncertainties & $\begin{array}{l}\text { Garthwaite and Eckert (2012); Lueke and } \\
\text { Ariaratnam (2000); Li and Knights (2009); } \\
\text { Bannerman (2008); Alliau et al. (2016); Jones and } \\
\text { Lichtenstein (2009). }\end{array}$ \\
\hline $\begin{array}{l}\text { Risk management and human and cultural } \\
\text { factors }\end{array}$ & $\begin{array}{l}\text { Whelan et al. (2004); Ávila Filho et al. (2015; 2016); } \\
\text { Wybo and Van Wassenhove (2016); Almutairi et al. } \\
\text { (2019). }\end{array}$ \\
\hline Project management in crisis times & $\begin{array}{l}\text { Kesavan (2016); Viliani et al. (2016); Power et al. } \\
\text { (2013); Rousseaux and Lhoste (2008); Cabal and } \\
\text { Erlich (2018). }\end{array}$ \\
\hline Model of decision making in projects proposition & $\begin{array}{l}\text { Shafiee (2015); Almutairi et al. (2019); Toffolon } \\
\text { and Dakhli (2002); Xu and Li (2012). }\end{array}$ \\
\hline Water resource risk and project management & $\begin{array}{l}\text { Ousmane and Abdullah (2018); Macchiaroli et al. } \\
\text { (2019); Genco et al. (2005); Hurlimann (2007); } \\
\text { Che et al. (2014); Li et al. (2020). }\end{array}$ \\
\hline
\end{tabular}

Source: authors (2020).

According to the papers, studies about software engineering projects, risks and failures arise in the organization where it is developed, due to the organizational changes in which software projects operate or result from external economic, technological, socio-political and regulatory factors that tend to impact organizations, and your operations (Bannerman, 2008).

Regarding project management risks for possible floods, Penning-Rowsell et al. (2013) listed some uncertainties, such as cost estimation (since it is an unconventional project and complex in terms of time, cost, and environmental and social impacts), measurement of the quantity of raw material needed, impact on the quality and volume of water, levels of indirect impacts on business and navigation.

The approach about the risks inherent in the use of treated water depends directly on the source of the waste (gray water, wastewater, rainwater, for example) due to the presence of different biological pathogens and product chemicals. Treatment effectiveness is directly related to the efficiency of the treatment system (Hurlimann, 2007). Yet Hurlimann (2007) categorizes the risks related to the quality of treated water, the risks to the health of individuals and domestic animals, the different domestic uses, the costs of the treatment system, among others. Through risk assessment in the water supply.

Shafiee (2015) considers that the risks associated with wind farms can be grouped into two groups: risks of system failures (lack of energy) and environmental risks (natural disasters, ship collisions).

In the resource extraction sector, social responsibility risk occurs at the operational level and, as such, needs to be managed locally as part of the operation itself. This shows that social responsibility risk is complex, and can present financial, infrastructure, and market risk characteristics. At the local level, extraction projects have risks: delays in planning, lawsuits, 
interruptions in production, storage costs, delays in construction, and project cancellation or expropriation (Norman et al., 2017).

Regarding civil construction, Zeng et al. (2010) analyze twenty risks, categorizing them into electrocution, environmental harms, falling from a height, falling objects, fires and explosions, structure, use of equipment, use of a motor. Also, Zeng et al. (2010) concluded that roof-related falls, elevator shaft falls, holes in flooring on the construction sites, hit by falling objects, and run over by operating equipment, are graded to be unacceptable. $\mathrm{Xu}$ and $\mathrm{Li}$, (2012) add that in the construction site, construction projects, the perception, and divergence between project managers are subjective uncertainties, while those caused by external factors (level of demand, prices, and variety of materials, defects in equipment, variable task times, and delays) are considered more objective.

Finally, Viliani et al. (2016) assessed the risk management in infectious diseases of the ore mining industry, analyzing and mitigate the risks of contagion, promoting partnerships between the industry, public health systems, and other relevant stakeholders. Thus, they realized that preventive and effective measures for the continuation of mining services included: provision of primary medical services and partnerships for the treatment of more serious cases, easy access to guidelines to avoid contagion, conducting epidemiological surveillance, reporting diseases notifiable to local health services, perceptions of vulnerability to the external environment, the existence of strong structures and management systems, among other actions.

\section{CONCLUSIONS}

This study aimed to analyze international scientific productions that simultaneously addressed the themes of engineering project management in times of crisis and risk management amid a scenario. This paper sought to answer the following research questions: ( $R Q \# 1)$ Which are the main topics relating the crisis and risk management to the engineering project context? (RQ\#2) What are the tools, actions and skills needed for risk and crisis management in engineering projects? (RQ\#3) What are the most updated thoughts, trends and gaps in the literature?

Studies related to this theme, aim to analyze the risks and uncertainties so that the immediate decisions do not compromise the organizations or the success of the projects. Projects in Software Engineering and Water Resources areas were the most recurrent in the sample. Studies in these areas aim to solve problems in the short and medium-term so that the company or the community is not negatively affected. Also, there is a concern with human resources about their skills and knowledge in the face of emergencies and crises, as reported in some French papers. This fact is reported by other authors in the software engineering area when project management and monitoring systems fail or need updates in the face of new situations. For this reason, many papers proposed models for decision making, based on lessons learned on the project, crisis, and risk management, responding to (\#RQ1).

Analyzes made in session 3 respond to (\#RQ2) by exposing the tools and measures that the authors consider important for risk and crisis management. Despite these authors do not only restrict the use of software but analyze the behavior of the management actions and skills of the project team, arguing that management measures and immediate risk analysis require that the project manager can control multitasking.

Answering the question (\#RQ3), these studies analyzed were developed in post-crisis environments, be they environmental, economic, or even in the project itself. The selected papers analyze the consequences and risks inherent in these situations and recommend the creation of lessons learned that can be shared and that helps project managers. There is an emerging line of research relating to the concept of crisis software and risk management. Some authors argue that software crises are associated with a set of problems in Software Engineering projects, related to use, development processes, maintenance, and resource management. 
However, the scientific papers were not concerned with measuring, through indicators, the impact that crises and risks would have on the project's timeline, time, and budgets. Another important aspect that was not mentioned in the papers, how these critical events influence sustainable project performance, making the project unfeasible or only a pause in execution or planning.

Another aspect is government participation in risk control and budget incentives for the design and execution of engineering projects, as happened after the Xynthia storm occurred in Western Europe in 2010. Other research has shown a concern to assess risks through mathematical and computational models, especially when it comes to economic crises. This scenario changes the contact relations and pricing of products and services, mainly in infrastructure, mining, energy, and fuel projects, as occurred in 2008.

Through bibliometric indicators and content analysis across the sample, it was possible to realize that the immediacy of managerial actions to control risk in the face of crises requires project managers to have exceptional project management skills, such as the ability to assess the consequences of a decision on multiple tasks.

Finally, this study has limitations related to the number of productions and state of the art on the subject, as it may vary with time. As future studies, there is a creation of a risk list addressed and categorized by the engineering area.

\section{REFERENCES}

Alliau, D., Balayn, P. and Ouf, D. (2016), "Tools for crisis management: from flood forecasting to flood maps for coordination of operations", Houille Blanche, Vol. 1, pp. 50-6.

Almutairi, A., Collier, Z.A., Hendrickson, D. et al. (2019), "Stakeholder mapping and disruption scenarios with application to resilience of a container port", Reliability Engineering \& System Safety, Vol. 182, pp. 219-32.

Ávila Filho, S., Carvalho, A.C.F., Portela, G.P.J. et al. (2015), "Learning environment to take operational decision in emergency situation", Procedia Manufacturing, Vol. 3, pp. 1780-7.

Ávila Filho, S., Ferreira, J.F.M.G., Oliveira Sousa, C.R. et al. 2016), “Dynamics operational risk management in organizational design, the challenge for sustainability", in 50th Annual Loss Prevention Symposium 2016, LPS 2016 - Topical Conference at the 2016 AIChE Spring Meeting and 12th Global Congress on Process Safety, New York, NY, pp. 431-53.

Ayağ, Z. and Özdemir, R.G. (2009), "A hybrid approach to concept selection through fuzzy analytic network process", Computers \& Industrial Engineering, Vol. 56, No. 1, pp. 368-79.

Baccarini, D. (1996), "The concept of project complexity: a review", International Journal of Project Management, Vol. 14, No. 4, pp. 201-4.

Baldi, C., Martelli, M., Treu, C. (2012), “Territorial vulnerability analysis: the environmental risk management systems", in Brebbia, C.A. (Ed.), Risk Analysis IV. WIT Press, Southampton.

Bally, P., Béquignon, J., Arino, O. et al. (2005), "Remote sensing and humanitarian aid: a life-saving combination", European Space Agency Bulletin, Vol. 122, pp. 36-41.

Bannerman, P.L. (2008), “Toward an integrated framework of software project threats”, in Proceedings of the Australian Software Engineering Conference, Perth, WA, Australia, pp. 139-48.Bubnov, G., Titarenko, B., Titov, S. et al. (2015), "Isorisk curves as a tool for increasing flexibility of risk management in engineering projects", Contemporary Engineering Sciences, Vol. 8, No. 21, pp. 991-9.

Cabal, A. and Erlich, M. (2018), "Flood risk management approaches and tools for mitigation strategies of coastal submersions and preparedness of crisis management in France", International Journal of River Basin Management, Vol. 16, No. 3, pp. 353-69.

Carvalho, M.M. (2013), "An investigation of the role of communication in IT projects", International Journal of Operations \& Production Management, Vol. 34, No. 1, pp. 36-64, available at: http://www.emeraldinsight.com/doi/10.1108/IJOPM-11-2011-0439 (accessed 2 February 2020).

Carvalho, M.M., Fleury, A. and Lopes, A.P. (2013), "An overview of the literature on Technology Roadmapping (TRM): contributions and trends", Technological Forecasting and Social Change, Vol. 80, No. 7, pp. 1418-37. 
Che, W., Zhao, Y., Yang, Z. et al. (2014), "Integral stormwater management master plan and design in an ecological community", Journal of Environmental Sciences, Vol. 26, No. 9, pp. 1818-23.

Chiu, C.-Y. and Park, C.S. (1994), "Fuzzy cash flow analysis using present worth criterion", The Engineering Economist, Vol. 39, No. 2, pp. 113-38.Consoni, S. and Colauto, R.D. (2016), "Voluntary disclosure in the context of convergence with international accounting standards in Brazil", Review of Business Management, Vol. 18, No. 62, pp. 658-77. http://dx.doi.org/10.7819/rbgn.v18i62.2242.

Duriau, V.J., Reger, R.K. and Pfarrer, M.D. (2007), "A content analysis of the content analysis literature in organization studies: research themes, data sources, and methodological refinements", Organizational Research Methods, Vol. 10, No. 1, pp. 5-34. http://dx.doi.org/10.1177/1094428106289252.

El Emam, K. and Koru, A.G. (2008), "A replicated survey of IT software project failures", IEEE Software, Vol. 25, No. 5, pp. 84-90.

Fairley, R. (1994), "Risk management for software projects", IEEE Software, Vol. 11, No. 3, pp. 57-67.

Garthwaite, P.M. and Eckert, C. (2012), “Glitches, snags and crises: a study of change in hospital adaptation projects", in ARCOM 2012 - Proceedings of the 28th Annual Conference, Reading, pp. 1089-99.

Genco, M., Arena, C. and Mazzola, M.R. (2005), "Assessing the risk of water supply in drought-prone areas”, in Proceedings of the 8th International Conference on Computing and Control for the Water Industry, CCWI 2005: Water Management for the 21st Century, England.

Geraldi, J., Maylor, H. and Williams, T. (2011), "Now, let's make it really complex (complicated)", International Journal of Operations \& Production Management, Vol. 31, No. 9, pp. 966-90.

Holla, K., Kampova, K., Peterkova, A. et al. (2013), "Complex model of risk assessment of industrial processes mopori", Komunikacie, Vol. 15, No. 2, pp. 63-8.Howsawi, E., Eager, D., Bagia, R. et al. (2014), "Success strategies for project management during national crises: insights from the british aviation industry during world war two", International Review of Management and Business Research, Vol. 3, No. 1, pp. 24.

Hurlimann, A.C. (2007), "Is recycled water use risky? An urban Australian community's perspective", The Environmentalist, Vol. 27, No. 1, pp. 83-94.Ikpaahhindii, L. (1985), "An overview of bibliometrics: its measurements, laws and their applications", Libri, Vol. 35, No. 2, pp. 163.

Jones, C. and Lichtenstein, B.B. (2009), “Temporary inter-organizational projects: how temporal and social embeddedness enhance coordination and manage uncertainty", in Cropper, S., Huxham, C., Ebers, M., Ring, P. S. (Eds.), The Oxford Handbook of Inter-Organizational Relations, Oxford University Press, Oxford.Keeling, R. (2005), Gestão de Projetos: Uma Abordagem Global. Saraiva, São Paulo.

Kesavan, S. (2016), "Project management in times of crisis", in Abu Dhabi International Petroleum Exhibition and Conference 2016, Abu Dhabi, UAE.

Kostuk, K.J., Sparks, G.A. and Tadros, G. (2006), "Comparing conventional and innovative bridge deck options: a life cycle engineering and costing approach", in Proceedings of the 3rd International Conference on Bridge Maintenance, Safety and Management - Bridge Maintenance, Safety, Management, Life-Cycle Performance and Cost, Porto, Portugal, pp. 983-84.

Kroener, I., Barnard-Wills, D. and Muraszkiewicz, J. (2019), "Agile ethics: an iterative and flexible approach to assessing ethical, legal and social issues in the agile development of crisis management information systems", Ethics and Information Technology. In press.

Ledford, H. (2015), "CRISPR, the disruptor", Nature, Vol. 522, No. 7554, pp. 20-4.

Li, D., Zhang, J., Wang, G. et al. (2020), "Impact of changes in water management on hydrology and environment: a case study in north China", Journal of Hydro-environment Research, Vol. 28, pp. 75-84.

Li, S.-X. and Knights, P. (2009), "Integration of real options into short-term mine planning and production scheduling", Mining Science and Technology, Vol. 19, No. 5, pp. 674-8.Littell, J.H., Corcoran, J. and Pillai, V. (2008), Systematic Reviews and Meta-Analysis. Oxford University Press, Oxford.

Liu, J., Jin, F., Xie, Q. et al. (2017), "Improving risk assessment in financial feasibility of international engineering projects: a risk driver perspective", International Journal of Project Management, Vol. 35, No. 2, pp. 204-11.

Lueke, J.S. and Ariaratnam, S.T. (2000), "Subsurface ground movements associated with trenchless pipe replacement methods", in Proceedings of Construction Congress VI: Building Together for a Better Tomorrow in an Increasingly Complex World, Orlando, Florida, pp. 778-87. 
Macchiaroli, M., Pellecchia, V. and D'Alpaos, C. (2019), "Urban water management in Italy: an innovative model for the selection of water service infrastructures", WSEAS Transactions on Environment and Development, Vol. 15, pp. 463-77.

Masso, J., Pino, F.J., Pardo, C. et al. (2020), "Risk management in the software life cycle: a systematic literature review", Computer Standards \& Interfaces, Vol. 71, 103431.

Miller, R. and Lessard, D. (2001), "Understanding and managing risks in large engineering projects", International Journal of Project Management, Vol. 19, No. 8, pp. 437-43.

Molina Palma, M.A., Andrade, J.L.P. and Pedro, J.D.S. (2011), "Gestão de riscos em projeto: contornando incertezas para viabilizar a implantação de nova tecnologia em uma indústria petrolífera de E\&P", Revista de Gestão e Projetos, Vol. 2, No. 2, pp. 102-22.

Moral-Muñoz, J.A., Herrera-Viedma, E., Santisteban-Espejo, A. et al. (2020), "Software tools for conducting bibliometric analysis in science: an up-to-date review", El Profesional de la Información, Vol. 29, No. 1, pp. 1-20.

Moreno, C. (2005), Risk Reduction of On-Board Software Development Cycle, European Space Agency, (Special Publication), Paris, pp. 195-97.

Muhuri, P.K., Shukla, A.K. and Abraham, A. (2019), "Industry 4.0: a bibliometric analysis and detailed overview", Engineering Applications of Artificial Intelligence, Vol. 78, pp. 218-35.Neely, A. (2005), "The evolution of performance measurement research", International Journal of Operations \& Production Management, Vol. 25, No. 12, pp. 1264-77. http://dx.doi.org/10.1108/01443570510633648.

Norman, J.S., Strobl, M. and Moldovan, S. (2017), "A methodology for integrating social responsibility into management systems", in Asia Pacific Health, Safety, Security, Environment and Social Responsibility Conference 2017, Kuala Lumpur, Malaysia.

Ousmane, S. and Abdullah, A. (2018), "From top-down to bottom-up approaches to risk discovery: a paradigm shift in climate change impacts and adaptation studies related to the water sector", in 6th International Disaster Mitigation Specialty Conference 2018, Held as Part of the Canadian Society for Civil Engineering Annual Conference 2018, Fredericton, Canada, pp. 146-56.

Paggio, R., Agre, G., Dichev, C. et al. (1999), "A cost-effective programmable environment for developing environmental decision support systems", Environmental Modelling \& Software, Vol. 14, No. 5, pp. 367-82.

Paraskevas, A. and Quek, M. (2019), "When Castro seized the Hilton: risk and crisis management lessons from the past", Tourism Management, Vol. 70, pp. 419-29.Pearson, C.M. and Clair, J.A. (1998), "Reframing crisis management", Academy of Management Review, Vol. 23, No. 1, pp. 59-76. http://dx.doi.org/10.5465/amr.1998.192960.

Penning-Rowsell, E.C., Haigh, N., Lavery, S. et al. (2013), "A threatened world city: the benefits of protecting london from the sea", Natural Hazards, Vol. 66, No. 3, pp. 1383-404.

Pinheiro, A.A., Siani, A.C., Guilhermino, J.F. et al. (2006), "Metodologia para gerenciar projetos de pesquisa e desenvolvimento com foco em produtos: uma proposta", Revista de Administração Pública, Vol. 40, No. 3, pp. 457-78.

Power, R., Robinson, B., Wise, C. et al. (2013), "Information integration for emergency management: recent CSIRO case studies", in Proceedings - 20th International Congress on Modelling and Simulation, MODSIM 2013, Adelaide, South Australia, pp. 2061-67.

Project Management Institute - PMI. (2004), A Guide to the Project Management Body of Knowledge (PMBOK® Guide), PMI, Pennsylvania.

Project Management Institute - PMI. (2013), A Guide to the Project Management Body of Knowledge (PMBOK® Guide), PMI, Pennsylvania.

Rahahleh, A.H. and Omoush, M.M. (2019), "The role of business intelligence in crises management: a field study on the telecommunication companies in Jordan", International Business Research, Vol. 13, No. 1, pp. 221.

Raz, T., Shenhar, A.J. and Dvir, D. (2002), "Risk management, project success, and technological uncertainty", R \& D Management, Vol. 32, No. 2, pp. 101-9.

Reid, D., Yost, T., Russell, I. et al. (2016), "Avoiding the money pit: the industrialization of delivering complex drilling facilities", in SPE/IADC Drilling Conference, Proceedings, Texas, USA.

Rousseaux, F. and Lhoste, K. (2008), "Process analysis, modeling and simulation for crisis management", in Proceedings - International Workshop on Advanced Information Systems for Enterprises, IWAISE 2008, Constantine, Algeria, pp. 41-45. 
Rovai, R.L., Cattini Junior, O. and Plonski, G.A. (2013), "Gestão de riscos em projetos de inovação atráves da abordagem contingencial: análise conceitual e proposição de modelo estruturado para redução de incertezas em projetos complexos", Review of Administration and Innovation, Vol. 10, No. 3, pp. 269-95.

Sawle, W.S. (1991), "Crisis project management", PM Network, Vol. 5, No. 1, pp. 25-9.

Schimak, G., Ignjatović, D., Vullings, E. et al. (2020), "Interoperability of solutions in a crisis management environment showcased in Trial-Austria", in ISESS 2020: Environmental Software Systems. Data Science in Action, Wageningen, The Netherlands, pp. 173-87.Scopus (2018), "Scopus global research", available at: https://www.elsevier.com/_data/assets/pdf_file/0017/114533/Scopus_GlobalResearch_Factsheet2019_FIN AL_WEB.pdf (accessed 12 August 2020).

Shafiee, M. (2015), "A fuzzy analytic network process model to mitigate the risks associated with offshore wind farms", Expert Systems with Applications, Vol. 42, No. 4, pp. 2143-52.

Shenhar, A. (2011), "Meeting time, cost, and money-making goals with Strategic Project Leadership®", in PMI® Global Congress 2011, Dallas, TX.

Söderlund, J. and Lenfle, S. (2013), "Making project history: revisiting the past, creating the future", International Journal of Project Management, Vol. 31, No. 5, pp. 653-62.

Song, J., Hu, Y. and Feng, Z. (2018), "Factors influencing early termination of PPP projects in China", Journal of Management Engineering, Vol. 34, No. 1, 05017008.

Szczepaniak, R., Defarge, I. and Chevenier, C. (2001), "Technical data exchange for collaborative work in complex systems", in Proceedings of DASIA 2002, Noordwijk, Netherlands, pp. 358-67.Takey, S.M. and Carvalho, M.M. (2016), "Fuzzy front end of systemic innovations: a conceptual framework based on a systematic literature review", Technological Forecasting and Social Change, Vol. 111, pp. 97-109. http://dx.doi.org/10.1016/j.techfore.2016.06.011.

Toffolon, C. and Dakhli, S. (1998), "A framework for software engineering inconsistencies analysis and reduction", in Proceedings - International Computer Software and Applications Conference, Vienna, Austria, pp. 270-77.

Toffolon, C. and Dakhli, S. (2002), "The software engineering global model", in Proceedings-IEEE Computer Society's International Computer Software and Applications Conference, Oxford, UK, pp. 47-52.

Vencato, M.F. (2014), "Ferramenta para análise e avaliação de riscos no planejamento de projetos de pesquisa e desenvolvimento", Revista de Gestão e Projetos, Vol. 5, No. 2, pp. 102-11.

Viliani, F., Edelstein, M., Omaar, A. et al. (2016), "A collaborative approach to infectious disease preparedness: the IDRAM initiative", in International Conference and Exhibition on Health, Safety, Security, Environment, and Social Responsibility, Stavanger, Norway.

Wagner, J., Jones, M. and Nash, K. (2016), "Issue management and sustainability: lessons from a major oilfield development in Madagascar", in International Conference and Exhibition on Health, Safety, Security, Environment, and Social Responsibility, Stavanger, Norway.

Watremez, X., Labat, N., Audouin, G. et al. (2016), "Remote detection and flow rates quantification of methane releases using infrared camera technology and 3D reconstruction algorithm", in Proceedings - SPE Annual Technical Conference and Exhibition, Dubai, UAE.

Whelan, C.D., Aeiker, J., Downey, S. et al. (2002), "Industrial electric power systems operating competency: a looming crisis?", in Record of Conference Papers - Annual Petroleum and Chemical Industry Conference, New Orleans, LA, USA, pp. 197-202.

Whelan, C.D., Aeiker, J., Downey, S. et al. (2004), "A looming crisis", IEEE Industry Applications Magazine, Vol. 10, No. 2, pp. 51-6.Wideman, R.M. (1992), Project and Program Risk Management: A Guide to Managing Project Risks and Opportunities. Project Management Institute, Pennsylvania.

Wong, S. (2012), "Wicked' social capital eludes design: how poor mainland chinese migrants coped with the far east economic crisis", in Daniere, A., Van Luong, H. (Eds.), The Dynamics of Social capital and Civic Engagement in Asia, Routledge, London.

Wybo, J.-L. and Van Wassenhove, W. (2016), "Preparing graduate students to be HSE professionals", Safety Science, Vol. 81, pp. 25-34.

Xu, J. and Li, Z. (2012), "Multi-objective dynamic construction site layout planning in fuzzy random environment", Automation in Construction, Vol. 27, pp. 155-69.Yellow Brick Consulting (2020), "Keeping your project on track during a crisis", available at: https://www.emeraldgrouppublishing.com/opinion-and-blog/keepingyour-project-track-during-a-crisis (accessed 12 October 2020). 
Zeng, S.X., Tam, C.M. and Tam, V.W.Y. (2010), "Integrating safety, environmental and quality risks for project management using a FMEA method", The Engineering Economist, No. 1, pp. 44-52.

Zhu, J. and Mostafavi, A. (2018), "Performance assessment in complex engineering projects using a system-of-systems framework", IEEE Systems Journal, Vol. 12, No. 1, pp. 262-73.

Zied Milian, E., Spinola, M.M. and Carvalho, M.M. (2017), "Risks and uncertainties in cloud computing: literature review, trends and gaps", IEEE Latin America Transactions, Vol. 15, No. 2, pp. 349-57.

Author contributions: All the authors contributed equally to this paper. 